\title{
ALTERATION OF P53 CONFORMATION AND INDUCTION OF APOPTOSIS IN A MURINE ERYTHROLEUKEMIA CELL LINE BY DIMETHYLSULFOXIDE
}

\author{
James J. Ryan and Michael F. Clarke \\ Division of Hematology/Oncology, Department of Internal Medicine. University of Michigan Medical \\ Center, Ann Arbor, MI 48109-0668. U.S.A.
}

(Received 5 November 1993. Revision accepted 22 February 1994)

\begin{abstract}
Programmed cell death, or apoptosis, may play an important role in the regulation of hematopoiesis. The tumor suppressor protein $\mathrm{p} 53$ has been identified as a key regulator of apoptosis in both normal and malignant hematopoietic cells. Modulation of p53 function is of interest, therefore, both in understanding the control of apoptosis and as a potential therapeutic intervention. In this study we describe the effect on murine erythroleukemia cells, transfected with a temperature-sensitive mutant p53, of exposure to the differentiating agent dimethylsulfoxide (DMSO). Rather than terminally differentiating, these cells are induced to undergo apoptosis. Interestingly, exposure to DMSO leads to an alteration of the protein conformation of the p53 mutant to one recognized by a wild-type specific monoclonal antibody. This is accompanied by a translocation of the p53 protein from the cytoplasm to the nucleus. These results suggest that the activity of some mutant $\mathrm{p} 53$ proteins can be functionally modified by exogenous compounds.
\end{abstract}

Key words: p53, apoptosis, erythroleukemia, dimethylsulfoxide, protein conformation, transfection.

\section{Introduction}

Programmed Cell Death, or apoptosis, is now thought to be an important regulatory process in normal hematopoiesis and in tumor suppression. Hematopoietic progenitor cells are dependent on cytokines not only for proliferation but also to prevent apoptosis [1]. The genetic regulation of apoptosis is poorly understood. Yonish-Roach $e t$ al. have shown that re-introduction of wild-type p53 expression induces apoptosis in the murine M1 myeloid leukemic cell line [2]. This effect is inhibited by exposure of M1 cells to the growth factor interleukin- 6 and enhanced by treatment with transforming growth factor beta [3]. Wild-type p53 expression is also necessary for some forms of induced apoptosis in normal hematopoietic cells [4]. In the murine erythroleukemia (MEL) cell line

Abbreviations: $D M S O$, dimethylsulfoxide: $M E L$, murine erythroleukemia; $S V 40$, Simian virus $40 ; R S V L T R$, Rous sarcoma virus long terminal repeat.

Correspondence to: Michael F. Clarke, Division of Hematology/Oncology, University of Michigan Medical Center, 1150 West Medical Center Drive, C570 MSRB II. Ann Arbor, MI 48109-0668, U.S.A.
DP16-1, re-introduction of a temperature-sensitive p53 mutant ( $553^{\text {val-135})}$ allows the effect of wild-type p53 expression to be studied by temperature downshift [5]. The $\mathrm{p} 53^{\text {ts }}$ mutant behaves as a mutant p53 in cells cultured at $37^{\circ} \mathrm{C}$; at $32.5^{\circ} \mathrm{C}$ the protein undergoes a conformational change to that recognized by wild-type specific antibodies and is translocated from the cytoplasm to the nucleus in rat embryo fibroblast cells $[6,7]$. Transfer of DP16-1 MEL cells transfected with a p5 $3^{\text {ts }}$ expression vector to $32.5^{\circ} \mathrm{C}$ results in $\mathrm{G} 1$ cell cycle arrest and subsequent apoptotic cell death [5]. This is accompanied by movement of p53 into the cell nucleus.

Murine erythroleukemia cells can be induced to differentiate into mature red cells by treatment with a number of chemical agents, including dimethylsulfoxide (DMSO). DP16-1 cells exposed to $1.6 \%$ DMSO will differentiate, as measured by benzidine staining for hemoglobin content, over a period of 4 5 days. When DP16-1 cells transfected with $\mathrm{p} 53^{\text {ts }}$ are treated with DMSO at $37^{\circ} \mathrm{C}$, apoptosis, rather than differentiation, ensues in the majority of cells. Antibody studies demonstrate that this is correlated with a conformational change in the $\mathrm{p} 53$ protein and nuclear localization. This finding suggests that p53 activity 
TABLE 1. VIABILITY AND DIFFERENTIATION OF DP16-1 AND p53 ${ }^{\text {ts }}$ TRANSFECTED MEL CELLS CULTURED IN $1.6 \%$ DMSO

\begin{tabular}{rrrrr}
\hline & $\begin{array}{c}\text { DP16-1 } \\
\text { Viability } \\
\text { Benzidine+ }\end{array}$ & \multicolumn{2}{c}{$\begin{array}{c}\text { C9 } \\
\text { Viability } \\
\text { Benzidine+ }\end{array}$} \\
\hline $0 \mathrm{~h}$ & $97 \%$ & $<5 \%$ & $96 \%$ & $<5 \%$ \\
$24 \mathrm{~h}$ & $95 \%$ & $<5 \%$ & $71 \%$ & $<5 \%$ \\
$48 \mathrm{~h}$ & $91 \%$ & $12 \%$ & $41 \%$ & $<5 \%$ \\
$72 \mathrm{~h}$ & $89 \%$ & $33 \%$ & $29 \%$ & $<5 \%$ \\
$96 \mathrm{~h}$ & $86 \%$ & $64 \%$ & $10 \%$ & $8.5 \%$ \\
$120 \mathrm{~h}$ & $85 \%$ & $81 \%$ & $4.5 \%$ & $\mathrm{ND}$ \\
\hline
\end{tabular}

MEL cells were cultured in $1.6 \%$ DMSO for the indicated time periods ( $h=$ hours) at $37^{\circ} \mathrm{C}$ and viability determined by trypan blue exclusion and differentiation by benzidine staining for hemoglobin content. Each percentage given is the mean of three separate experiments; each data point was obtained from counting a minimum of 100 cells. The $120 \mathrm{~h}$ benzidine stain of the clone nine cells was not done (ND) secondary to an insufficient number of intact cells.

can be influenced through exposure to differentiating agents such as DMSO. Compounds influencing the cellular localization and function of mutant p53 are of potential therapeutic value.

\section{Materials and Methods}

Stable $p 53^{\text {ts }}$ transfectants

p5 $3^{\text {ts }}$ neo contains the coding sequence of the neomycin resistance gene under the regulation of an SV40 promoter and the coding sequences of $\mathrm{p}^{\text {val-135 }}$ linked to an RSV LTR promoter. This plasmid was derived from plasmid pLTRp53cG (a gift of M. Oren) as previously described [5]. $553^{\text {ts }}$ neo was linearized with BamHI and transfected into DP16-1 MEL cells (a gift of S. Benchimol) by electroporation, as previously described [5]. Transfected cells were selected in DMEM media containing $1 \mathrm{mg}$ of geneticin ( G418,GIBCO) per ml. Single cell clones were isolated by limiting dilution in 96-well microtiter plates. To induce differentiation, logarithmically growing cells were grown in medium containing 1.6\% DMSO (Sigma) for a total of 5 days. Media were changed every other day. Benzidine staining was performed as previously described [5]. Cell viability was measured by trypan blue exclusion.

\section{p53 immunoprecipitation}

Clone 9 cells were cultured at $37^{\circ} \mathrm{C}$, with and without $1.6 \% \mathrm{DMSO}$, for $24 \mathrm{~h}$ and then labeled for $3 \mathrm{~h}$ with $0.2 \mathrm{mCi}$ of $\left.{ }^{35} S\right]$ methionine. Immunoprecipitations were performed as previously described $[5]$. Lysates $\left(2 \times 10^{6}\right.$ cells) were precipitated with PAb421, a pan-specific monoclonal antibody against p53, PAb246, a murine p53-specific monoclonal antibody that recognizes wild-type p53, and PAb240, a p53-specific monoclonal antibody that recognizes an epitope present on mutant forms of p53 [7]. Untransfected parental DP16-1 MEL cells were immunoprecipitated with the same antibodies as a negative control. Immune complexes were collected with protein A agarose beads



FIG. 1. DNA fragmentation in p53-induced apoptosis. Genomic DNA ( $3 \mu \mathrm{g}$ ) was extracted [5] from clone 9 cells (lane a) and DP16-1 cells (lane b) after incubation for $24 \mathrm{~h}$ in DMEM media containing 1.6\% DMSO. DNA was then analyzed by electrophoresis through a $1.5 \%$ agarose gel. An apoptotic ladder is clearly seen in DNA derived from the clone 9 cells.

(Bethesda Research Laboratories), washed three times in lysis buffer, electrophoresed through $10 \%$ polyacrylamide in the presence of SDS and dried gels used for autoradiography.

\section{Immunohistochemistry}

Clone 9 cells were cultured at $37^{\circ} \mathrm{C}$ in the presence and absence of $1.6 \%$ DMSO for $24 \mathrm{~h}$. Untransfected DP16-1 cells were grown at $37^{\circ} \mathrm{C}$ as a negative control. $2.5 \times 10^{5}$ cells were then suspended in FACS buffer [5] and pelleted 

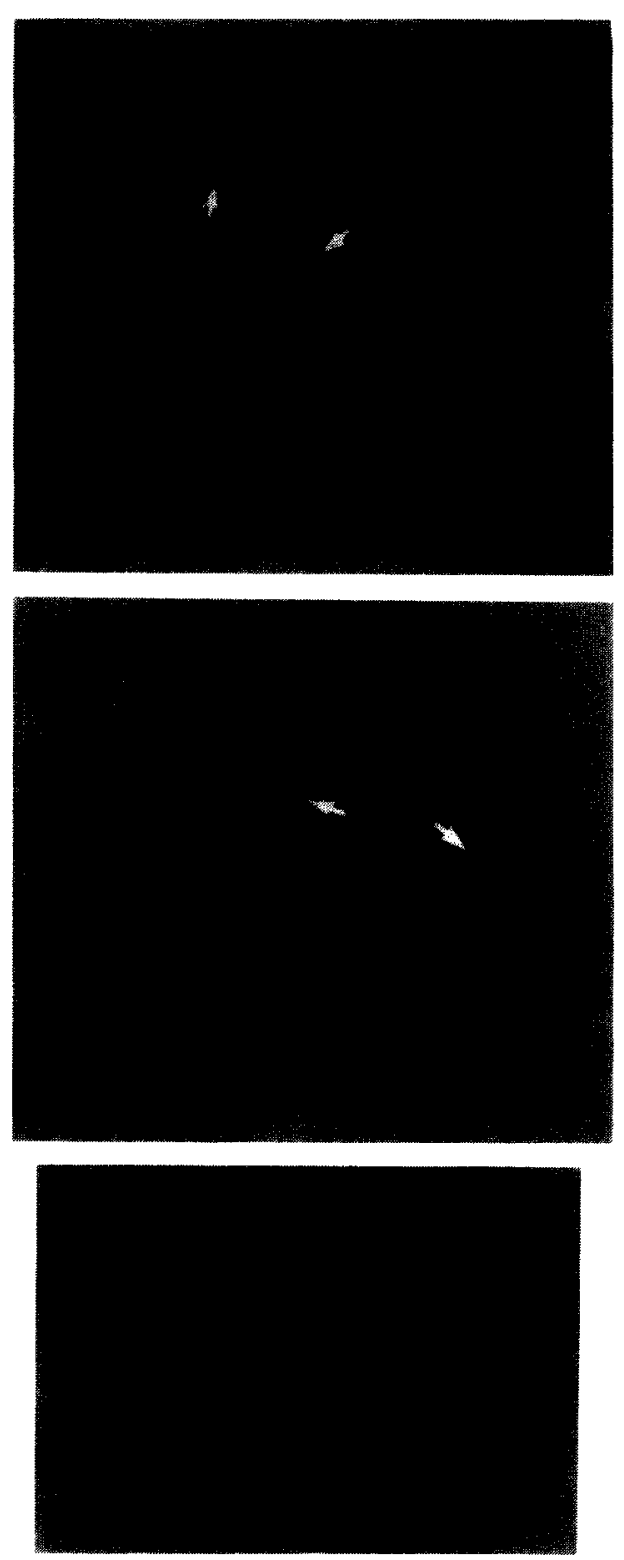

FIG. 2. Immunohistochemistry showing the cellular localization of p53 at $37^{\circ} \mathrm{C}$ in the presence and absence of $1.6 \%$ DMSO. The lower panel shows the untransfected parental cell line DP16-1 stained with PAb421; DP16-1 has no detectable expression of endogenous p53. The middle panel shows $053^{\text {ts }}$ neo transfected DP16-1 cells (clone 9) grown at $37^{\circ} \mathrm{C}$ without added DMSO and the expected cytoplasmic staining (white arrows) is seen. The upper panel demonstrates the nuclear staining (white arrows) seen in clone 9 cells cultured in $1.6 \%$ DMSO for $24 \mathrm{~h}$ prior to p53 staining.

on a microscope slide using a cytospin centrifuge (Shandon). Cells were fixed with methanol for $1 \mathrm{~h}$ at $4^{\circ} \mathrm{C}$ and then washed in PBS. Forty microliters of PAb421 were added to each slide for $1 \mathrm{~h}$ at room temperature. Following a PBS wash, $25 \mu \mathrm{l}$ of GAM-FITC (Tago) were added for $1 \mathrm{~h}$ at room temperature. Staining was visualized by fluorescence microscopy.

\section{Results}

Several DP16-1 $\mathrm{p} 53^{\text {ts }}$ transfected subclones were studied by culture at $37^{\circ} \mathrm{C}$ in the presence of $1.6 \%$ DMSO. These clones have previously been shown to express p53-specific RNA and protein [5]. In contrast to the parental cell line DP16-1, which maintains viability and differentiates over a 4-5 day period (Table 1), the p53 transfectants lose viability, with most cells dying prior to developing positive benzidine staining. Data for a representative clone, C9, are shown in Table 1. Apoptosis is characterized by activation of an endogenous endonuclease leading to fragmentation of genomic DNA secondary to internucleosomal cleavage. This pattern is clearly seen in C9 cells exposed to $1.6 \%$ DMSO for $24 \mathrm{~h}$, while only high molecular weight DNA is extracted from similarly treated DP16-1 cells (Fig. 1). This is consistent with an induction of apoptosis by p53 in the DMSO-treated $\mathrm{p} 53^{\text {ts }}$ transfectants.

Immunohistochemistry was then performed on $\mathrm{C} 9$ cells growing at $37^{\circ} \mathrm{C}$ with and without $1.6 \%$ DMSO for $24 \mathrm{~h}$. p53 staining clearly showed a nuclear pattern in DMSO-treated cells, as compared with the expected cytoplasmic staining of untreated cells (Fig. 2). Parental DP16-1 cells showed no p53-specific staining.

To examine whether a conformational change in the $\mathrm{p} 53^{\text {ts }}$ protein occurs with nuclear translocation, we performed p53 immunoprecipitations on C 9 cells growing in $1.6 \%$ DMSO. The monoclonal antibody PAb246 is specific for an epitope of the wild-type murine p53 conformation. At $37^{\circ} \mathrm{C}$ less than $5 \%$ of the $\mathrm{p} 53^{\mathrm{ts}}$ protein can be precipitated with $\mathrm{PAb} 246$, while a significantly higher proportion can be precipitated at $32.5^{\circ} \mathrm{C}[7,8]$. The mutant-specific monoclonal antibody PAb240 can detect the majority of p53 protein at $37^{\circ} \mathrm{C}$; these results are confirmed in $\mathrm{C} 9$ cells cultured at $37^{\circ} \mathrm{C}$ in the absence of DMSO (Fig. 3). Figure 4 shows that in DMSO-treated C9 cells at $37^{\circ} \mathrm{C}$ a significant proportion of the total p53 protein (as detected by the pan-specific antibody PAb421) is recognized by PAb246. In contrast, much less protein is precipitated with the mutant p53specific monoclonal antibody PAb240. This is consistent with a shift to a wild-type protein conformation secondary to DMSO exposure and would explain the observed nuclear localization of the p53 protein.

\section{Discussion}

The subcellular location of p53 is thought to modulate its actions. Mutant forms of the protein are often associated with the heat shock protein hsp 70 and 


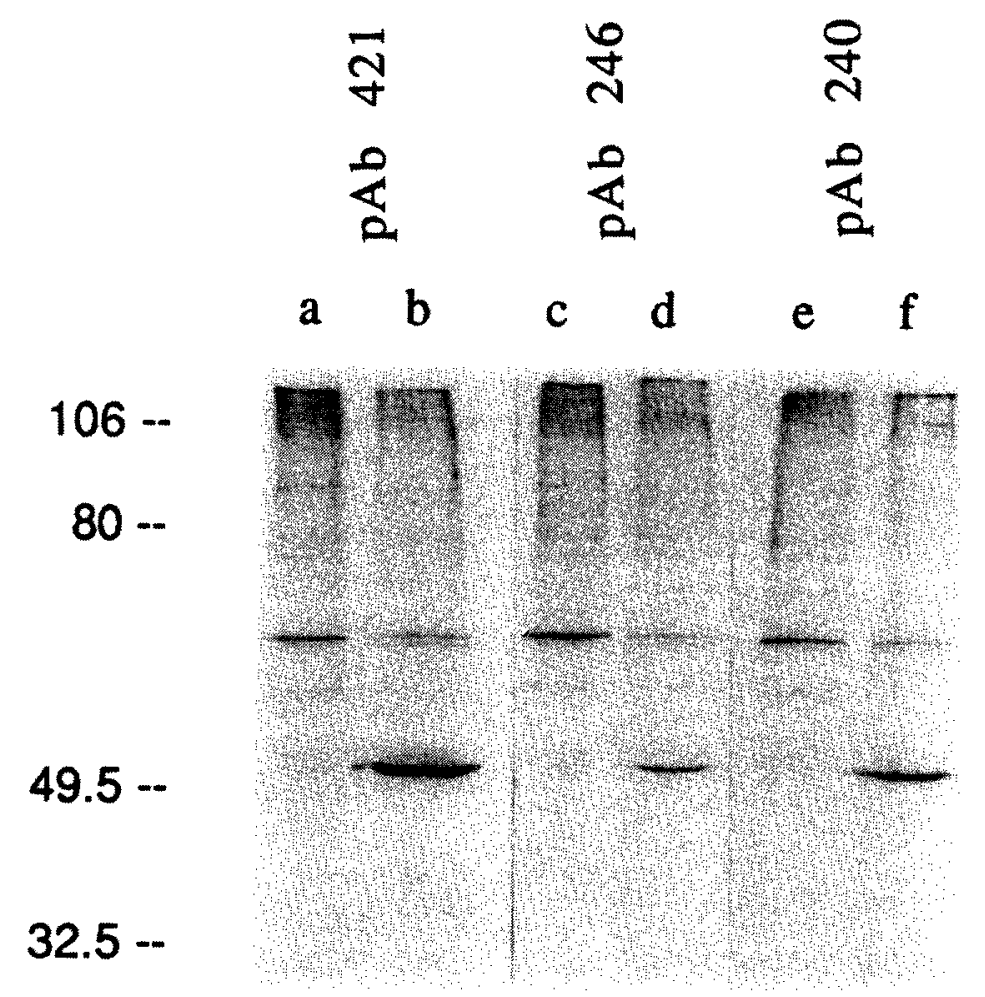

FIG. 3. Conformational analysis of $\mathrm{p} 53^{\mathrm{ts}}$ protein in clone 9 cells. p53 was immunoprecipitated using conformation specific monoclonal antibodies [7] from labeled parental DP16-1 (lanes a, c, e) and clone 9 cells (lanes b, d, f) cultured at $37^{\circ} \mathrm{C}$ without DMSO. A majority of the total protein (precipitated with the non-specific antibody PAb 421) is recognized by the mutant specific antibody $\mathrm{PAb} 240$. No precipitable protein is seen in the untransfected DP16-1 MEL cells with any of the antibodies used.

localized in the cytoplasm [9]. The temperature-sensitive mutant used in these experiments is localized in the cytoplasm when cells are grown at $37^{\circ} \mathrm{C}$ (when the protein is in a mutant conformation) and translocates into the nucleus when cells are grown at $32.5^{\circ} \mathrm{C}$ (when the 553 is in a wild-type conformation). In $\mathrm{p} 53^{\text {ts }}$ MEL cells nuclear localization of the $\mathrm{p} 53$ protein is associated with G1 growth arrest and apoptosis [5]. Interleukin-6 treatment of M1 myeloid leukemia cells inhibits $\mathrm{p} 53$-induced apoptosis without affecting nuclear translocation [10]. The factors regulating transport of p53 intracellularly are not known. Evidence has been presented that a short-lived protein is responsible for anchoring mutant p53 in the cytoplasmic compartment [11]. Downregulation of this putative protein might, therefore, allow entry of p53 into the nucleus. Alternatively, a change in p53 protein conformation may allow release from a cytoplasmic anchoring protein.

In this study exposure of $\mathrm{p} 53^{\text {ts }}$ transfected MEL cells to DMSO resulted in nuclear translocation of the 533 protein. Immunoprecipitation data support the concept that a change in protein conformation allows entry into the nucleus. The $\mathrm{p} 53$ is functionally active and fundamentally alters the phenotype of cells cultured in DMSO. During normal myeloid differentiation p53 protein levels increase [12]. Entry of $\mathrm{p} 53$ into the nuclear compartment during induced differentiation may be important in its role as a tumor suppressor protein; apoptosis would be induced in those cells with extensive DNA damage or genetic alterations while differentiation would be promoted in less mutated cells. This idea is supported by the finding that wild-type p53 can promote differentiation in a chronic myelogenous leukemia cell line [13], as well as in murine erythroleukemia cells ([8], Ryan J. \& Clarke M. F., unpublished observations). An understanding of the factors regulating the subcellular localization of $\mathrm{p} 53$ will be an important step in the development of targeted cancer therapeutics.

Acknowledgements-NCI-CA 46657 (M. Clarke). 


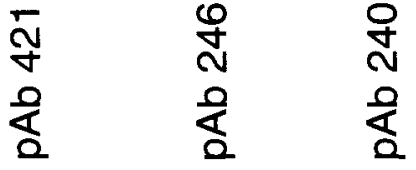

$106-$

$80-$

$49.5-$

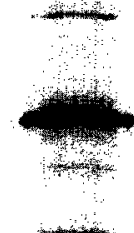

32.5

FIG. 4. Conformational analysis of $\mathrm{p} 53^{\text {ts }}$ protein in clone 9 cells. p53 was immunoprecipitated using conformationspecific monoclonal antibodies [7] from labeled clone 9 cells exposed to $1.6 \%$ DMSO for $24 \mathrm{~h}$. A significant proportion of the total p53 protein (precipitated with PAb421) is recognized by the wild-type specific antibody PAb246 while a smaller percentage is recognized by the mutant conformation specific antibody PAb240.

\section{References}

1. Koury M. J. \& Boudarant M. C. (1990) Erythropoietin retards DNA breakdown and prevents programmed death in erythroid progenitor cells. Science 248, 378.

2. Yonish-Roach E., Resnitzky D., Lotem J., Sachs L., Kimchi A. \& Oren M. (1991) Wild-type p53 induces apoptosis of myeloid leukaemic cells that is inhibited by interleukin-6. Nature 352, 345.

3. Yonish-Roach E., Grunwald D., Wilder S., Kimchi A., May E., Lawrence J.-J., May P. \& Oren M. (1993) p53-mediated cell death: relationship to cell cycle control. Molec. Cell. Biol. 13, 1415.

4. Lotem J. \& Sachs L. (1993) Hematopoietic cells from mice deficient in wild-type p53 are more resistant to induction of apoptosis by some agents. Blood 82, 1092.

5. Ryan J. J., Danish R., Gottlieb C. A. \& Clarke M. F. (1993) Cell cycle analysis of p53 induced cell death in murine erythroleukemia cells. Molec. Cell. Biol. 13, 711.

6. Ginsburg D., Michalovitz D. M., Ginsberg D. \& Oren M. (1991) Induction of growth arrest by a temperaturesensitive p53 mutant is correlated with increased nuclear localization and decreased stability of the protein. Molec. Cell. Biol. 11, 582.

7. Michalovitz D., Halevy O. \& Oren M. (1990) Conditional inhibition of transformation and of cell proliferation by a temperature-sensitive mutant of $\mathrm{p} 53$. Cell 62, 671.

8. Jehnson P., Chung S. \& Benchimol S. (1993) Growth suppression of Friend virus-transformed erythroleukemia cells by p53 protein is accompanied by hemoglobin production and is sensitive to erythropoietin. Molec. Cell. Biol. 13, 1456.

9. Finlay C. A., Hinds P. W., Tan T. H., Eliyahu D., Oren M. \& Levine A. J. (1988) Activating mutations for transformation by $\mathrm{p} 53$ produce a gene product that forms an hsc 70-p53 complex with an altered half-life. Molec. Cell. Biol. 8, 531.

10. Levy N., Yonish-Roach E., Oren M. \& Kimchi A. (1993) Complementation by wild-type p53 of interleukin-6 effects on M1 cells: induction of cell cycle exit and cooperativity with c-myc suppression. Molec. Cell. Biol. 13, 7942.

11. Gannon J. V. \& Lane D. P. (1991) Protein synthesis required to anchor a mutant $\mathrm{p} 53$ protein which is temperature-sensitive for nuclear transport. Nature 349, 802.

12. Kastan M. B., Radin A. I., Kuerbitz S. J.. Onyekwere O., Wolkow C. A., Civin C. I., Stone K. D., Woo T., Ravinchranath Y. \& Craig R. W. (1991) Levels of p53 protein increase with maturation in human hematopoietic cells. Cancer Res. 51, 4279.

13. Feinstein E., Gale R. P., Reed J. \& Canaani E. (1992) Expression of the normal p53 gene induces differentiation of $\mathrm{K} 562$ cells. Oncogene 7, 1853. 